\title{
Seronegative and seropositive rheumatoid arthritis treated with rituximab
}

\author{
Maria Luisa Velloso Feijoo*, Rosalia Martínez Pérez, Lucia González Mayordomo, Jose Luis Marenco de la Fuente \\ From 7th European Workshop on Immune-Mediated Inflammatory Diseases \\ Noordwijk aan Zee, the Netherlands. 28-30 November 2012
}

\section{Background}

B cells play a crucial role in the pathogenesis of rheumatoid arthritis (RA). They are responsible for the autoantibodies formation such as rheumatoid factor (RF) and anti- cyclic citrullinated peptide antibodies (anti$\mathrm{CCP}$ ) and the production of cytokines, act as antigen presenting cells and regulate $\mathrm{T}$ cell functions.

Rituximab (RTX), murine monoclonal antibody which selectively targets CD20-positive B-cells, has proved to be an efective and safe therapy for active RA. Initially it was used in seropositive RA, but considering the other functions of B cells, it is logical to think that it is also useful in seronegative forms.

\section{Objective}

To evaluate the efficacy of RTX in our series of refractory seronegative and seropositive RA.

\section{Materials and methods}

Baseline characteristics and disease activity markers at baseline, and after 3 and 6 months of treatment with RTX ( 1 g x 2 weeks), were collected in 33 patients. A descriptive study was made; and the relations between variables were analyzed statistically.

\section{Results}

The mean age was $52.06 \pm 12.01$ years, $75.8 \%$ female, $78.8 \%$ RF positive (26). The mean duration of illness was $7.70 \pm 4.47$ years. Thirty-two patientes $(97 \%)$ had failed at least to one TNF antagonist.

Most of the patients $(84.8 \% 9)$ received RTX with methotrexate.

The mean DAS28 at baseline was $5.7 \pm 1.30$; at 3 months decreased to $3.4 \pm 1.22$, and at 6 months to $4.15 \pm 1.69(\mathrm{p}<0.0005)$.

At 3 months, $88.9 \%$ reached good eular response, and $63.3 \%$ at 6 months. Remission was obtained in $17.2 \%$ at 3 months and in $16.7 \%$ at 6 months.

It was also noted improvement in baseline $\mathrm{HAQ}$, after 3 and 6 months (from $1.75 \pm 0.767$ to $0.96 \pm 0.56$ and $1.24 \pm 0.70$ respectively).

No significant differences were found between decreases in DAS 28 at 3 and 6 months compared to baseline between RF seronegative and seropositive patients, neither in good eular response, remission percentages or HAQ improvement. The data are shown in the table.

\section{Discussion}

The efficacy and safety of RTX has been proved in several clinical trials.

The presence of RF, low baseline functional disability and no more than one previous anti-TNF are predictors of good response to RTX, as has been recently published.

Response rates in seronegative RA, are slightly lower, although higher than placebo, as described in other publications.

\section{Table 1}

\begin{tabular}{|c|c|c|c|c|c|c|c|c|c|c|}
\hline & $\begin{array}{l}\text { Mean } \\
\text { DAS28 at } \\
\text { baseline }\end{array}$ & $\begin{array}{l}\text { Mean } \\
\text { DAS28 at } \\
3 \text { months }\end{array}$ & $\begin{array}{l}\text { Mean } \\
\text { DAS28 at } \\
6 \text { months }\end{array}$ & $\begin{array}{l}\text { Good eular } \\
\text { response at } \\
3 \text { months }\end{array}$ & $\begin{array}{l}\text { Good eular } \\
\text { response at } \\
6 \text { months }\end{array}$ & $\begin{array}{c}\text { DAS } 28<2,6 \\
\text { at } 3 \text { monts }\end{array}$ & $\begin{array}{l}\text { DAS28<26 } \\
\text { at } 6 \text { months }\end{array}$ & $\begin{array}{l}\text { HAQ at } \\
\text { baseline }\end{array}$ & $\begin{array}{l}\text { HAQ at } 3 \\
\text { months }\end{array}$ & $\begin{array}{l}\mathrm{HAQ} \text { at } 6 \\
\text { months }\end{array}$ \\
\hline $\mathrm{RF}+$ & $5.73 \pm 1.24$ & $3.38 \pm 1.30$ & $4.13 \pm 1.83$ & $90.5 \%$ & $65.2 \%$ & $18.2 \%$ & $17.4 \%$ & $1.81 \pm 0.77$ & $1.00 \pm 0.57$ & $1.2 \pm 0.74$ \\
\hline RF - & $5.52 \pm 1.61$ & $3.72 \pm 0.93$ & $4.22 \pm 1.23$ & $83.3 \%$ & $57.1 \%$ & $14.3 \%$ & $14.3 \%$ & $1.57 \pm 0.78$ & $0.83 \pm 0.56$ & $0.95 \pm 0.54$ \\
\hline
\end{tabular}

Rheumatology Unit, Valme University Hospital, Seville, Spain 
In conclussion, the experience of RTX treatment in our patients with seronegative RA is positive, in terms of efficacy, due to the action on B cells and their different roles, with no significant differences comparing to seropositive RA.

Published: 28 November 2012

\section{References}

1. Chatzidionysiou $K$, et al: Highest clinical effectiveness of rituximab in autoantibody-positive patients with rheumatoid arthritis and in those for whom no more than one previous TNF antagonist has failed: pooled data from 10 European registries. Ann Rheum Dise 2011, 70:1575-80.

2. Tak PP, Cohen SB, CK Saadeh, De Vita S, Donohue JP, Shaw TM, et al: Following the first response Clinical course Treatment with Rituximab: Effect of baseline autoantibody status / RF, anti-CCP). Ann Rheum Dis 2007, 66(Suppl II):338, [Abstract FRI0192].

doi:10.1186/1479-5876-10-S3-P47

Cite this article as: Velloso Feijoo et al:: Seronegative and seropositive rheumatoid arthritis treated with rituximab. Journal of Translational Medicine 2012 10(Suppl 3):P47.

\section{Submit your next manuscript to BioMed Central} and take full advantage of:

- Convenient online submission

- Thorough peer review

- No space constraints or color figure charges

- Immediate publication on acceptance

- Inclusion in PubMed, CAS, Scopus and Google Scholar

- Research which is freely available for redistribution

Submit your manuscript at www.biomedcentral.com/submit
C Biomed Central 